\title{
Potent Human p140-TrkA Agonists Derived from an Anti-Receptor Monoclonal Antibody
}

\author{
Lynne LeSauteur, ${ }^{1}$ Sergei Maliartchouk, ${ }^{1}$ Hélène Le Jeune, ${ }^{1,3}$ Remi Quirion, ${ }^{1,3}$ and H. Uri Saragovi ${ }^{1,2}$ \\ ${ }^{1}$ Department of Pharmacology and Therapeutics, ${ }^{2} \mathrm{McGill}$ Cancer Center, and ${ }^{3}$ Department of Psychiatry and Douglas \\ Hospital Research Center, McGill University, Montréal, Québec, Canada H3G 1 Y6
}

\begin{abstract}
Monoclonal antibody $(\mathrm{mAb}) 5 \mathrm{C} 3$ directed against human $\mathrm{p} 140$ TrkA is a structural and functional mimic of nerve growth factor (NGF) and an artificial receptor agonist. mAb $5 \mathrm{C} 3$ binds in the NGF-docking site and, like NGF, it promotes TrkA internalization, TrkA and phosphatidylinositol-3 kinase tyrosine phosphorylation, and increased transformation of TrkA-expressing fibroblasts. More important, mAb $5 \mathrm{C} 3$ protects human TrkA-
\end{abstract}

expressing cells from apoptotic death in serum-free media. Interestingly, agonistic activity is observed with monomeric $F_{a b}$ $5 \mathrm{C} 3$ fragments. mAb $5 \mathrm{C} 3\left(\mathrm{~K}_{\mathrm{d}} \sim 2 \mathrm{~nm}\right)$ was used to study features of ligand binding by TrkA and the distribution of TrkA protein in normal human brain.

Key words: NGF; receptor; TrkA; agonist; antibody; ligand
The TrkA receptor is a $140 \mathrm{kDa}$ transmembrane glycoprotein with tyrosine kinase activity that functions as the nerve growth factor (NGF) receptor (Kaplan et al., 1991; Klein et al., 1991). NGF also binds with low affinity to a 75 receptor the signaling function of which is unclear (Chao, 1992). Homodimers of TrkA or heterodimers of $\operatorname{Trk} \Lambda$ and $\mathrm{p} 75$ bind NGF with higher affinity (Hempstead et al., 1991; Jing et al., 1992; Mahadeo et al., 1994), suggesting that specific receptor conformations may play specific functions.

TrkA protein or mRNA are expressed in neural crest-derived sensory and sympathetic neurons, possibly in cholinergic neurons (Cavicchioli et al., 1991), within the basal forebrain and striatum (Holtzman et al., 1992; Verge et al., 1992), and in some nunneuronal tissues (Chevalier et al., 1994). Functional studies of neuronal cultures in vitro have suggested that TrkA protein is expressed throughout the cell surface (Campenot et al., 1994). However, whether this also is true within the architecture of the brain remains to be established.

NGF promotes the differentiation of certain neuronal cells, is mitogenic for TrkA-transfected fibroblast $\dot{s}$, and allows survival in serum-deprived conditions for both cell types. Activation of the tyrosine kinase activity of Trk $\Lambda$ via NGF binding leads to receptor trans- and auto-tyrosine phosphorylation (PY), and PY of second messengers including phosphatidylinositol-3 kinase (PI-3 kinase) (Soltoff et al., 1992). PI-3 kinase is involved in protein trafficking and endocytosis of ligand-receptor complexes (for review, see Kaplan and Stephens, 1994). Because microinjection of NGF into

Reccived June 21, 1995; revised Nov. 9, 1995; accepted Nov. 17, 1995.

This work was supported by grants from the Medical Research Council of Canada and Fonds pour la Formation de Chercheurs et l'Aide à la Recherche (Québec) to H.U.S. L.L.S. was supported by a Fellowship of the Medical Research Council of Canada. R.Q. is a Chercheur Boursier of the Fonds de la Recherche en Santé du Québec. We are grateful to Drs. M. Barbacid (Bristol-Myers-Squibb), M. Chao (Cornell University), E. Bogenmann (University of Southern California), and P. Barker (McGill University) for reagents. We also thank Drs. N.-K. V. Cheung (Memorial Sloan-Kettering Cancer Center), P. Barker (McGill University), and B. Collier (McGill University) for criticism and careful review of this manuscript, and we thank N. Lavine for expert technical assistance.

Correspondence should be addressed to H. Uri Saragovi, McGill University, Pharmacology and Therapeutics, 3655 Drummond Avenue 1320, Montréal, Quéhec, Canada H3G 1 Y6.

Copyright (C 1996 Society for Neuroscience $0270-6474 / 96 / 161308-09 \$ 05.00 / 0$ cells does not induce NGF biological signals (Heumann et al., 1984), cell-surface receptor ligation and internalization of TrkA or NGF-TrkA complexes must mediate these effects.

'I'rkA, like most kinase growth factor receptors, signals through receptor oligomerization (Heldin, 1995). Thus, monovalent TrkAbinding agents are antagonistic or have no biological effects (Clary et al., 1994; LeSauteur et al., 1995), whereas bivalent receptorbinding agents such as NGF (a homodimer; Bradshaw et al., 1993) or antibodies can be agonistic. The principle of using polyclonal antibodies to activate neural receptors has been demonstrated previously (Clary et al., 1994; Twyman et al., 1995). In contrast, only a limited number of anti-receptor monoclonal antibodies mimic ligand functions (Galloway et al., 1992; Taub and Greene, 1992), and none exists against neurotrophin receptors.

In this study, we report the development and characterization of an agonistic anti-human TrkA mAb 5C3 that recognizes the NGF-docking site. mAb $5 \mathrm{C} 3$ was used to characterize the pattern of TrkA protein expression in normal human brain and the NGF-binding features of the receptor. mAb $5 \mathrm{C} 3$ behaves like NGF in bioassays, and monomeric $5 \mathrm{C}_{3} \mathrm{~F}_{\mathrm{ab}}$ s retained binding and functional agonistic activity. $\mathrm{mAb} 5 \mathrm{C} 3$ will be useful to identify the NGF-docking sitc on TrkA and possibly as a pharmacological lead in the development of small mimetics.

\section{MATERIALS AND METHODS}

\section{Antibodies}

Female Balb/c mice were immunized with Balb/c-3T3 cells transfected with human TrkA, and splenocytes were fused to SP2/0 myelomas by the general method of Gefter (1977). Hybridomas were screened by differential binding between untransfected and TrkA-transfected cells using a FACScan (Becton Dickinson, San Jose, CA) (see below). mAb 5C3 $[\operatorname{IgG} 1(\kappa)]$ was identified and subcloned three times. Rat anti-mousc IgG ( $\alpha$ mIgG; Sigma, St. Louis, MO), anti-phosphotyrosine mAb 4G10 (Upstate Biotechnology, Lake Placid, NY), and anti-PI-3 kinase polyclonal serum (Upstate Biotechnology) were purchased commercially, mouse anti-rat p75 mAb MC192 ascites were a gift from P. Barker, and anti-p65 $\mathrm{mAb}$ 87.92.6 (Co et al., 1985) was grown in our laboratory.

\section{Monomeric $m A b 5 C 3 F_{a b} s$}

$\mathrm{mAb} 5 \mathrm{C} 3$ was purified $(1 \mathrm{mg} / \mathrm{ml})$ with Protein $\mathrm{G}-$ Sepharose (Sigma) and digested with papain $(10 \mu \mathrm{g} / \mathrm{ml}$; Gibco, Toronto, Ontario, Canada) as described previously (Coligan et al., 1991). $\mathrm{F}_{\mathrm{at}} \mathrm{s}$ were repurified on 
KappaLock-Sepharose (Upstate Biotechnology) and Protein G-Sepharose and dialyzed against PBS. All products were characterized by SDS-PAGE under nonreducing or reducing conditions $(100 \mathrm{~mm}$ 2 -mercaptoethanol) to $>98 \%$ purity (data not shown). Control $\Gamma_{a b} s$ from anti-rat p75 mAb MC192 were prepared similarly.

\section{Cell lines}

Mouse SP2/0 myelomas, mouse R1.1 and EL4 thymomas, mouse NIH3 T3 fibroblasts, mouse 2B $4 \mathrm{~T}$ cell hybridomas, NGF-responsive rat $\mathrm{PC1} 2$ pheochromocytoma cells, human Jurkat T lymphomas, and human HeLa fibroblasts were used. NIH-3T3 cells transfected either with human p140trkA cDNA (E25 cells), with p75 cDNA (Z91 cells), or with p75 and p140trkA cDNAs (R7 cells) were provided by Dr. M. Barbacid (Jing et al., 1992). The trk-ncgative rat B104 neuronal cell line (expressing endogenous rat $\mathrm{p} 75$ ) and B104-transfected with human trkA cDNA (4-3.6 cells, expressing human TrkA and rat $\mathrm{p} 75$ ) were provided by Dr. E. Bogenmann (Bogenmann et al., 1995). All cells were cultured in RPMI media supplemented with 5-10\% fetal bovine serum (FBS) and antibiotics (Gibco). Transfectants were added the appropriate drug selection.

\section{FACScan}

Cells $\left(5 \times 10^{5}\right)$ in $0.1 \mathrm{ml}$ of binding buffer [HBSS, $0.1 \%$ bovine serum albumin (BSA), and $0.1 \% \mathrm{NaN}_{3}$ ] were incubated with the indicated concentration of $\mathrm{mAbs}$ or $\mathrm{F}_{\mathrm{ab}}$ s for $30 \mathrm{~min}$ at $4^{\circ} \mathrm{C}$, washed in binding buffer to remove excess primary antibody, and immunostained with fluoresceinated [fluorescein isothiocyanate (FITC)] goat anti-mouse IgG (FITC$\mathrm{G} \alpha \mathrm{mIgG}$ ), or anti-mouse Fab (FITC-G $\alpha \mathrm{mF}_{\mathrm{ab}}$; Sigma) secondary antibody for $30 \mathrm{~min}$ at $4^{\circ} \mathrm{C}$ (Bhandoola ef al., 1993). Cells were acquired and analyzed on a FACScan using the LYSIS II program. As negative controls (background fluorescence), mouse IgG (Sigma), mAb 192, or $192 \mathrm{~F}_{\mathrm{ab}}$ s were used as primary, followed by appropriate secondary.

\section{Biochemical analysis}

Cell lysates. For cell lysates, $33 \times 10^{6}$ cells $/ \mathrm{ml}$ were detergent-solubilized (lysis buffer $2 \%$ Nonidet P-40, $150 \mathrm{~mm} \mathrm{NaCl}, 50 \mathrm{~mm}$ Tris-glycine, $10 \mathrm{~mm}$ $\mathrm{NaF}, 50 \mu \mathrm{M} \mathrm{Na} \mathrm{VO}_{4}, 30 \mathrm{~mm}$ Na-pyrophosphate, $10 \mathrm{~mm}$ henzamidine, and $20 \mathrm{~mm}$ iodoacetamide, $\mathrm{pH} 7.8$ ) supplemented with protease inhibitors (2 $\mu \mathrm{g} / \mathrm{ml}$ soybean trypsin inhibitor, $10 \mu \mathrm{g} / \mathrm{ml}$ aprotinin, $5 \mathrm{~mm}$ phenylmethylsulfonyl fluoride, and $10 \mu \mathrm{g} / \mathrm{ml}$ leupeptin) for $30 \mathrm{~min}$ at $4^{\circ} \mathrm{C}$, followed by a 15 min centrifugation at $14,000 \times g$. Cleared supernatants were analyzed by SDS-PAGE directly (whole-cell lysates) or after immunoprecipitation.

Gel analysis. Cell lysates were prepared in Laemmli electrophoresis sample buffer and analyzed by SDS-PAGE under reducing $(100 \mathrm{~mm}$ 2-mercaptoethanol) or nonreducing conditions. Prestained protein markers (Gibco) were used as reference. Protein concentrations were quantitated by the biuret assay (Bio-Rad, Melville, NY) and by parallel Coomassie blue staining of SDS-PAGE gels. For Western blotting, samples were electrotransferred to polyvinylidene difluoride (Xymotech Biosystems, Mt. Royal, Montréal, Québee, Canada), blocked overnight in TRST $(0.05 \mathrm{M}$ Tris base, $0.2 \mathrm{M} \mathrm{NaCl}, 0.5 \%$ Tween-20, pH 7.6) containing $1 \%$ BSA (Sigma), and immunoblotted with the indicated primary mAbs. Secondary antibodies were either horseradish peroxidase (HRP)conjugated goat anti-rabbit IgG (HRP-G $\alpha$ R) or goat anti-mouse IgG (HRP-G $\alpha$ M; Sigma). For detection the enhanced chemoluminescence (ECL) reagents (Amersham, Oakville, Ontario, Canada) were used according to the manufacturer's instructions. Densitometric analysis was performed with a Masterscan interpretive densitometer (Scanalytics, Billerica, MA) and a Scanmaster (Howtek, Hudson, NH).

\section{Binding, competition, and internalization assays}

mAb 5C3 was ${ }^{125}$ I-labeled by the Iodogen (Pierce, Rockford, IL) method (Harlow and Lane, 1988) to a specific activity of $\left.1.8 \mathrm{mCi} / \mathrm{mg} .{ }^{125} \mathrm{I}\right] 5 \mathrm{C} 3$ was repurified from free ${ }^{125} \mathrm{I}$ with Sephadex $\mathrm{G} 25$ columns $\left(15 \times 1 \mathrm{~cm}^{2}\right)$ to $>96 \%$ trichloroacetic acid-precipitable incorporation. Binding studies were performed with serial dilutions of $\left[{ }^{125} \mathrm{I}\right] 5 \mathrm{C} 3$ on $0.5 \times 10^{6} \mathrm{E} 25$ or 4-3.6 cells (and their respective controls, NIH-3T3 and B104 cells; data not shown) for $1 \mathrm{hr}$ at $4^{\circ} \mathrm{C}$. Cell-associated $\left[{ }^{125} \mathrm{I}\right] 5 \mathrm{C} 3$ and free $\left[{ }^{125} \mathrm{I}\right] 5 \mathrm{C} 3$ were counted after washing unbound ligand. Parallel $\left[{ }^{125} \mathrm{I}\right] \mathrm{NGF}$ (70 $\mathrm{mCi} / \mathrm{mg}$; DuPont NEN, Mississauga, Ontario, Canada)-binding assays were performed as control (data not shown). Competition of $\left[{ }^{125} \mathrm{I}\right] 5 \mathrm{C} 3$ binding was done in binding assays in the presence of unlabeled $\mathrm{mAb} 5 \mathrm{C} 3$ (100-fold molar excess) or unlabeled NGF (500-fold molar excess, saturating concentration).
Competition of $\left[{ }^{125} \mathrm{I}\right] \mathrm{NGF}$ binding was performed by first incubating cells with excess unlabeled mAb 5C3, NGF, mAb 87.92.6, or vehiclebinding buffer for $30 \mathrm{~min}$ at $4^{\circ} \mathrm{C} .\left[{ }^{125} \mathrm{I}\right] \mathrm{NGF}$ then was added to a final saturating concentration of $-1 \mathrm{nM}$, the mixturcs werc incubated for an additional $45 \mathrm{~min}$ at $4^{\circ} \mathrm{C}$, cells were washed, and cell-associated $\left.{ }^{125} \mathrm{I}\right]$ NGF was determined.

For receptor internalization studies, cells were incubated with TrkAbinding agents $(0.01 \mu \mathrm{g}$ of $\mathrm{mAb} 5 \mathrm{C} 3,2 \mathrm{nM} \mathrm{NGF})$ or controls (mIgG, HBSS) for 20 min either at $37^{\circ} \mathrm{C}$ (internalization-permissive temperature) or at $4^{\circ} \mathrm{C}$ (internalization-nonpremissive temperature). After washing, cells were processed for surface TrkA immunofluorescence with $\mathrm{mAb}$ $5 \mathrm{C3}$ primary and FITC-G $\alpha \mathrm{mIgG}$ secondary as described above and analyzed by FACScan.

\section{Proliferation/survival assays}

Cells (5000 cells/well) in serum-free media (SFM; Gibco) supplemented with $0.1 \%$ BSA were added to 96-well plates (Falcon, Lincoln Park, NJ) containing serial dilutions of $\mathrm{NGF}, \mathrm{mAb} 5 \mathrm{C} 3$, control mAbs, mAb $5 \mathrm{C} 3$ $F_{a b}$ fragments, control mAb $192 F_{a b}$ fragments (data not shown), or serum (final 5\% FBS, normal growth conditions). Where indicated, $\mathbf{F}_{\mathrm{ab}} \mathrm{s}$ were externally cross-linked with goat anti-mouse $F_{a b}\left(G \alpha m F_{i b}\right.$, Sigma). Wells containing all culture conditions but no cells were used as blanks. The proliferative/survival profile of the cells was quantitated using the tetrazolium salt reagent 3-[4,5-dimethylthiazol-2-yl]-2,5diphenyltetrazolium bromide (MTT; Sigma) 48-72 hr after plating as initially described by T. Mosmann (Hansen et al., 1989). Optical density readings of MTT were done in an EIA Plate Reader model 2550 (Bio$\mathrm{Rad})$ at $600 \mathrm{~nm}$ with the blanks subtracted. Assays were repeated at least five times in quadruplicates.

\section{Foci-formation assays}

E25 cells $\left(15 \times 10^{4}\right)$ were plated in a $25 \%$ serum containing $0.35 \%$ soft agar mixture in the presence of $\mathrm{mIgG}$ control $(0.5 \mu \mathrm{g} / \mathrm{ml}), \mathrm{mAb} 5 \mathrm{C} 3(0.5$ $\mu \mathrm{g} / \mathrm{ml}$ ), or NGF ( $2 \mathrm{nM})$. Conditions were replenished every $3 \mathrm{~d}$, and foci were counted after 2 weeks.

\section{Immunocytochemistry of human brain tissues}

Human brain tissue was obtained from six males (age $71.7 \pm 4.6$ years) without signs of neurological or psychiatric disorders. Tissue blocks were prepared (mean time postmortem $16.2 \pm 3.5 \mathrm{hr}$ ) and stored at $-80^{\circ} \mathrm{C}$. Cryostat sections (20 $\mu \mathrm{m}$ thick) were fixed ( $4 \% \mathrm{p}$-formaldehyde, $0.1 \mathrm{M}$ phosphate, pH 7.4, for $1 \mathrm{hr}$ at $4^{\circ} \mathrm{C}$ ) and rinsed in PBS for $1 \mathrm{hr}$ at $4^{\circ} \mathrm{C}$. Immunocytochemistry was performed using avidin-biotin complex (Vectastain Elite kit, Vector Laboratories, Burlingame, CA) as described previously (Hsu et al., 1981). Primary mAb 5C.3 was used either as a 1:1000-1:4000 dilution of ascites or a 1:4 dilution of SFM culture supernatant. Nickel ammonium sulfate $(0.5 \%)$ was used to amplify the signal in the diaminobenzidine revelation step. Some sections also were stained with cresyl violet to facilitate the cytoarchitectural analysis. Negative controls were performed without primary antibody or with normal mouse IgG as primary and, in all cases, yielded no detectable immunolabeling.

\section{RESULTS}

\section{Characterization of $\mathrm{mAb} 5 \mathrm{C} 3$}

To assess mAb 5C3 specificity for human TrkA, cells expressing or lacking TrkA were screened for differential binding by FACScan analysis measuring cell-associated fluorescence. Binding of $\mathrm{mAb}$ 5C3 to nonpermeabilized TrkA-expressing cells demonstrated that it recognizes the extracellular domain of human TrkA (Table 1, Fig. 1A). Human TrkA transfectant lines 4-3.6, E25, and R7 bound $\mathrm{mAb} 5 \mathrm{C} 3$. In contrast, rat $\mathrm{PC} 12$ (expressing rat TrkA and rat p75), rat B104 (parental cells of 4-3.6, expressing rat p75), Z91 (NIH-3T3 transfected with p75), wild-type NIH-3T3, or NIH-3T3 cells transicntly transfectcd with human $\operatorname{trk} B$, rat $\operatorname{trk} A$, or rat $\operatorname{trk} B$ cDNA did not bind mAb 5C3. Thus, $\mathrm{mAb} 5 \mathrm{C} 3$ is specific for human TrkA, and coexpression of rat or human p75 does not interfere with binding.

The concentration of mAb $5 \mathrm{C} 3$ required to saturate TrkA receptors in E25 cells was determined by testing increasing amounts of antibody in FACScan assays (Fig. 1A). Receptor 


\begin{tabular}{|c|c|}
\hline Cells & $5 \mathrm{C} 3$ Binding \\
\hline E25 (hTrkA) & +++++ \\
\hline R7 (hTrkA/p75) & +++ \\
\hline $\mathrm{Z} 91(\mathrm{p} 75)$ & - \\
\hline 4-3.6 (hTrkA/p75) & +++ \\
\hline $\mathrm{B} 104(\mathrm{p} 75)$ & - \\
\hline $\mathrm{PC} 12$ (rTrkA/p75) & - \\
\hline \multicolumn{2}{|l|}{ Transient NIH-3T3 } \\
\hline \multicolumn{2}{|l|}{ Transfections } \\
\hline htrkA cDNA & ++ \\
\hline$h t r k B$ cDNA & - \\
\hline$r t r k B$ cDNA & - \\
\hline rtrkA cDNA & - \\
\hline
\end{tabular}

The indicated cell lines expressing hıman TrkA (hTrkA), rat TrkA (rTrkA), and/or p75 were analyzed by surface immunofluorocytometry with mAb $5 \mathrm{C} 3$ versus control $\mathrm{mIgG}$. Transient transfections ( $48 \mathrm{hr}$ ) were done by electroporation of cDNAs (provided by M. Chao). Relative intensities of staining are indicated as ++++ (high staining) or - (no staining, equivalent to background fluorescence; see Fig. 1). Saturating doses of $\mathrm{mAb}$ were used, and differences represent receptor number Other cells tested include wild-type NIH-3T3, Jurkat, R1.1, EL4, 2B4, and HeLa cells, which are all negative (data not shown).

saturation is evident at $2 \mu \mathrm{g} / \mathrm{ml} \mathrm{mAb} 5 \mathrm{C} 3$, at which concentration the fluorescence intensity is maximal. Similar analysis with $\mathrm{mAb}$ 5C3 $\mathrm{F}_{\mathrm{ab}} \mathrm{s}$ demonstrated that specificity (data not shown) and saturability were similar to that obtained with intact $m \Lambda b$. Lower $\mathrm{F}_{\mathrm{ab}}$ protein concentrations $(0.7 \mu \mathrm{g} / \mathrm{ml})$ were required for receptor saturation (Fig. 1B). Because the molecular weight of $5 \mathrm{C} 3 \mathrm{~F}_{\mathrm{ab}}$ is threefold lower than $5 \mathrm{C} 3 \mathrm{IgG}$ ( $\sim 50 \mathrm{vs} \sim 150 \mathrm{kDa}$, respectively), equimolar concentrations of $\operatorname{IgG}$ and $\mathrm{F}_{\mathrm{ab}}$ ligands were required to saturate hTrkA.

Western blot analysis with $\mathrm{mAb} 5 \mathrm{C} 3$ revealed heterogeneous material of $M_{\mathrm{r}} 140 \mathrm{kDa}(\mathrm{p} 140)$ for samples from E25 and 4-3.6 cells but not for control cells (Fig. $2 A$ ). In these cells, a band of $\sim 110 \mathrm{kDa}(\mathrm{p} 110)$ was also observed, previously thought to be intracellular TrkA precursors (Martin-Zanca et al., 1989). The p140 band also was immunoblotted in samples dissected from normal human cortex or nucleus basalis of Meynert (Fig. 2B). The p110 band was not seen, perhaps because of different posttranslational processing in neuronal tissues with respect to transfected cell lines. mAb 5C3 was effective in Western blot analysis only when samples were prepared under nonreducing conditions, indicating that a disulfide bond-stabilized conformational epitope is recognized.

\section{Immunostaining in normal human brain}

mAb 5C3 was used to map TrkA protein expression by immunocytochemistry of normal adult human brains. The striatum, basal forebrain, and brainstem exhibited the strongest immunostaining, whereas only weak staining could be detected in the cerebral cortex and hippocampal formation (Fig. 3).

All sectors of the basal nucleus contained large TrkA-positive neurons (Fig. 3A,C), most of them in groups embedded in a dense network of overlapping stained processes (Fig. $3 A$ ). The cells had heterogeneous shapes, ranging from complex multipolar to fusiform.

In the basal ganglia, TrkA was detected in distinct cellular compartments. The caudate nucleus, nucleus accumbens, and putamen contained several immunoreactive cell bodies without apparent distinction in density, perikaryal staining, or shape. Fig-

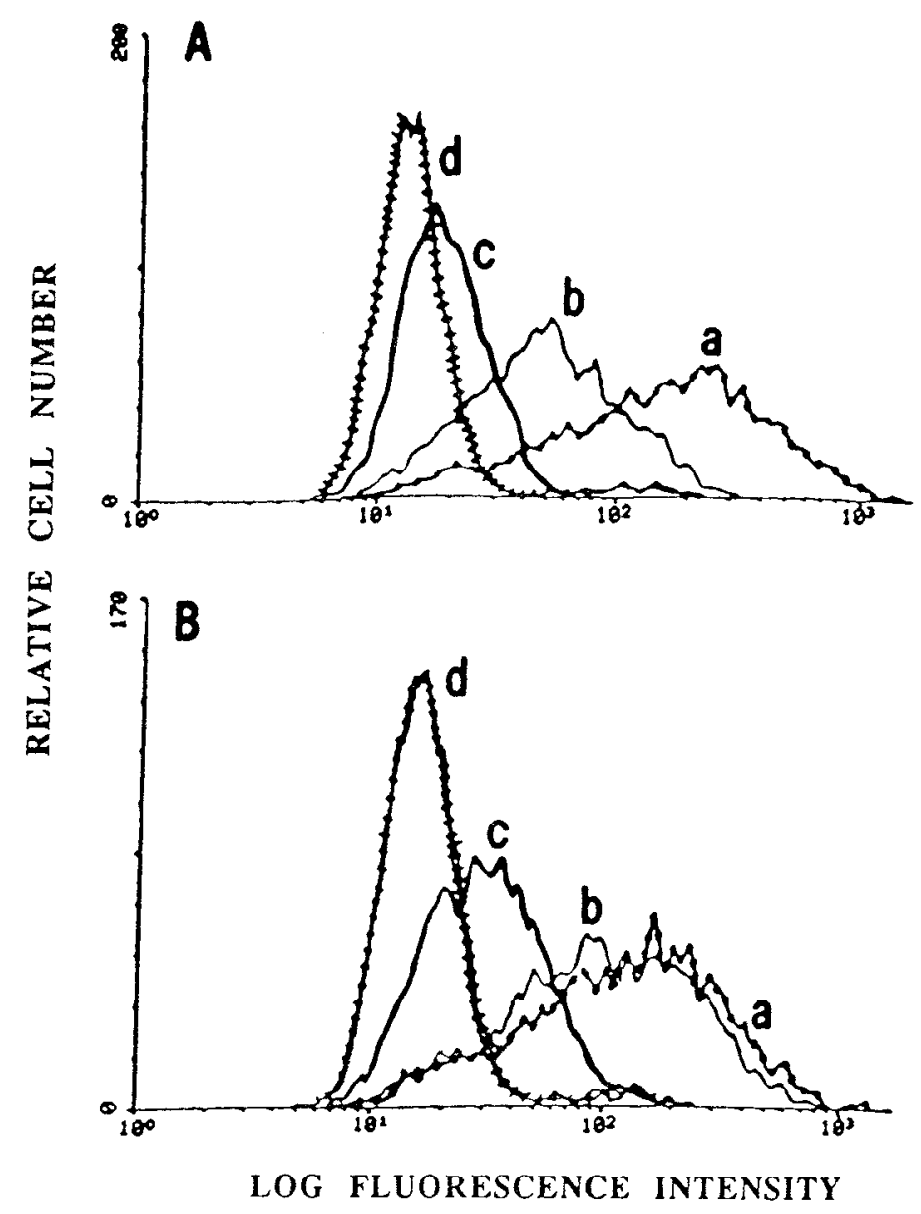

Figure 1. Surface immunofluorescence studies with mAb 5C3. E25 cells expressing human TrkA were analyzed by indirect FACScan immunofluorescence with various doses of mAb $5 \mathrm{C} 3$ or $5 \mathrm{C} 3 \mathrm{~F}_{\mathrm{ab}} \mathrm{s}$ to assess ligand concentrations that achieve receptor saturation. The areas under the curves represent the total number of cells acquired for each sample (constant 5000 cells). Histogram heterogeneity is attributable to individual cell receptor density. $A$, mAb $5 \mathrm{C} 3$ doses: $0.02 \mu \mathrm{g} / \mathrm{ml}$ (thick line, $c$ ); 0.2 $\mu \mathrm{g} / \mathrm{ml}$ (thin line, $b$ ); $2 \mu \mathrm{g} / \mathrm{ml}$ (dotted line, $a$ ). For background fluorescence, $\mathrm{mIgG}$ at $2 \mu \mathrm{g} / \mathrm{ml}$ (crossed line, $d$ ) was used. $B, 5 \mathrm{C} 3 \mathrm{~F}_{\mathrm{ab}} \mathrm{s}$ doses: $0.007 \mu \mathrm{g} / \mathrm{ml}$ (thick line, $c$ ) $; 0.07 \mu \mathrm{g} / \mathrm{ml}$ (thin line, $b$ ); $0.7 \mu \mathrm{g} / \mathrm{ml}$ (dotted line, $a$ ). For background fluorescence, $192 \mathrm{~F}_{\mathrm{abb}}$ at $0.7 \mu \mathrm{g} / \mathrm{ml}$ (crossed line, $d$ ) was used. Increased fluorescence intensity ( $x$-axis of histograms) reflects increased staining by mAb $5 \mathrm{C} 3$ or $5 \mathrm{C} 3 \mathrm{~F}_{\mathrm{ab}} \mathrm{s}$.

ure $3 D$ shows typical labeled multipolar neurons that displayed strong granular immunoreactivity around the nucleus and in proximal proccsscs. Moreover, numerous puncta and varicose fiber fragments were observed in these areas. The globus pallidus and claustrum were mostly negative except for varicose fibers. Similarly, the interstitial elements and fiber bundles did not contain reactive fibers, whereas the internal capsule displayed some labeled punctas and fibers, particularly near the putamen and caudate nucleus.

The hippocampal formation showed weak immunostaining located principally in scattered fibers and puncta in the stratum granulosum of the dentate gyrus, as well as in the strata oriens and pyramidale of Ammon's horn. In addition, some weakly stained perikarya could be observed in the stratum pyramidale of the CA2 and CA3 subfields of Ammon's horn and in the hilus of the dentate gyrus (CA4 subfield; Fig. $3 E$ ). The 
$\underline{\mathbf{A}}$

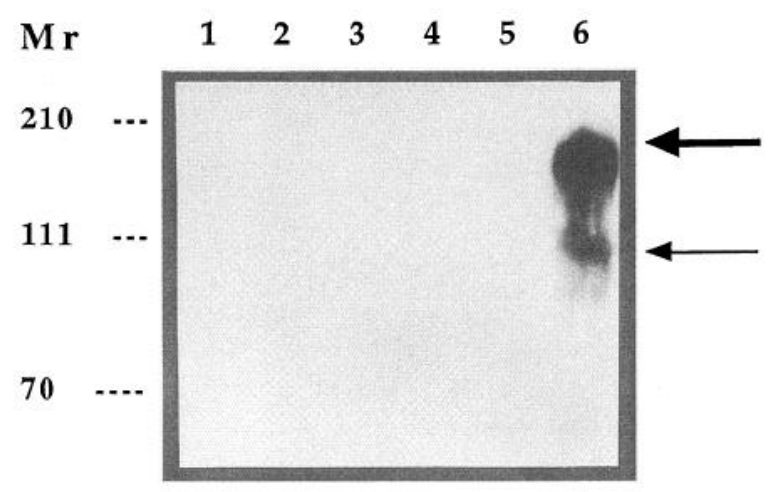

$\underline{\text { B }}$

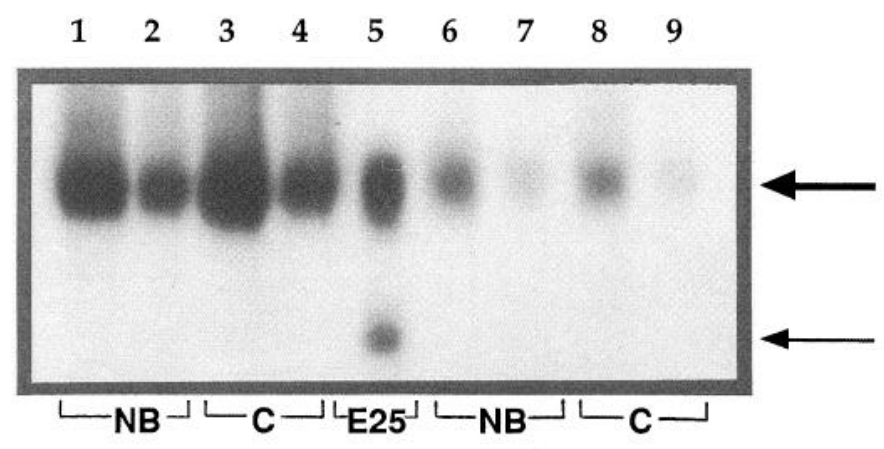

Figure 2. Direct detection of p140 TrkA by Western blotting. Whole-cell detergent lysates $\left(2 \times 10^{6}\right.$ cell equivalents/lane $)$ were resolved by SDSPAGE under nonreducing conditions and analyzed by Western blotting with mAb 5C3. A: Lane 1, Jurkat; lane 2, PC12; lane 3, NIH-3T3; lane 4, R1.1; lane 5, Z91; lane 6, E25. Thick arrow, p140 TrkA; thin arrow, p110. $B$, Dissected human brain tissues: nucleus basalis $(N B$; lanes $1,2,6,7)$ and cortex $(C$; lanes $3,4,8,9)$ were compared to E25 cells (lane $5 ; 2 \times 10^{5}$ cell equivalents). Lanes 1, 3, $300 \mu \mathrm{g} /$ lane; lanes 2, 4, $150 \mu \mathrm{g} /$ lane; lanes $6,8,75$ $\mu \mathrm{g} /$ lane; lanes $7,9,33 \mu \mathrm{g} /$ lane. Thick arrow, p140 TrkA; thin arrow, p110. Note that p110 is not seen in the human brain tissues.

perikarya of these neurons were relatively large, of ovoid to pyramidal shape, and bearing one prominent apical and radial dendritic process. The immunoreactivity appeared, as in other stained cell types of the brain, as small granular patches of precipitate located principally near the nuclear envelope and in some cases within the cytoplasm (Fig. $3 E$ ).

Within the cerebral cortex, particularly in the frontal area, TrkA immunoreactivity appeared more discrete. At high magnification, immunoreactive puncta and fiber fragments without a particular pattern of distribution are observed in all layers, but laminae III-VI appeared more stained than superficial ones (Fig. $3 H$ ). Weakly staining, medium-sized perikarya were occasionally observed in layer IV (Fig. 3H).

In the brainstem, TrkA staining also is detected. The pontine nuclei contained numerous immunoreactive, medium-sized globular perikarya and fibers between the pontocerebellar fibers (Fig. $3 F$ ). The reticular formation also displayed strong immunoreactivity for TrkA principally located in fiber networks (Fig. 3G). Some large neurons of bipolar or multipolar shape also are stained. No TrkA immunostaining was observed in the cerebellum (not shown).

\section{Binding studies}

Scatchard plot analysis of $\left[{ }^{125} \mathrm{I}\right] 5 \mathrm{C} 3$-binding assays demonstrated that in the E25 cell surface there are $\sim 250,000$ 5C3-binding sites/cell with a $K_{\mathrm{d}}$ of $1.6 \pm 1.0 \mathrm{~nm}$ (Fig. 4), and in the 4-3.6 cell surface there are $\sim 200,0005$ C3-binding sites/cell with a $K_{\mathrm{d}}$ of 3.0 $\pm 2.0 \mathrm{nM}$ (data not shown). No $\left[{ }^{125} \mathrm{I}\right] 5 \mathrm{C} 3$ binding was observed for parental NIH-3T3 or B104 cells (data not shown). Competition with saturating concentrations of NGF reduced the number of 5C3-binding sites in E25 cells by $\sim 25 \%$. However, NGF caused no detectable changes in the affinity of mAb $5 \mathrm{C} 3$ for TrkA receptors. Similar data were obtained measuring mAb 5C3-binding sites by FACScan analysis, in which a decrease was observed after NGF treatment (see Table 3).

In the converse experiment, mAb $5 \mathrm{C} 3$ inhibited $\sim 60 \%$ of $\left[{ }^{125} \mathrm{I}\right] \mathrm{NGF}$ binding to E25 cells. In these experiments, background binding was assessed by blocking with $5 \mu \mathrm{M}$ NGF (100\% inhibition), and maximal binding was assessed with binding buffer vehicle only ( $0 \%$ inhibition) or by using irrelevant binding mAb 87.92.6 (Table 2).

\section{Functional agonism of $\mathrm{mAb} 5 \mathrm{C3}$}

Several functional assays of NGF bioactivity were used to test the agonistic potential of mAb $5 \mathrm{C} 3$.

\section{Receptor internalization}

The 4-3.6 cells were treated with TrkA ligands at internalizationpermissive temperatures $\left(37^{\circ} \mathrm{C}\right)$ or at nonpermissive temperatures $\left(4^{\circ} \mathrm{C}\right.$; Table 3$)$. NGF treatment reduced the percent staining of mAb $5 \mathrm{C} 3$ to surface TrkA at both temperatures. Loss of surface 5C3-binding sites suggests direct blocking by NGF (see also Fig. 4). In contrast, $\mathrm{mAb} 5 \mathrm{C} 3$ treatment reduced the number of surface $5 \mathrm{C} 3$-binding sites only at $37^{\circ} \mathrm{C}$. This is likely attributable to receptor internalization, which does not occur efficiently at $4^{\circ} \mathrm{C}$. Treatment with $\mathrm{mIgG}$ or binding buffer control did not reduce the number of surface 5C3-binding sites at either temperature. Similar data were obtained with E25 cells (data not shown).

\section{Receptor PY}

Anti-phosphotyrosine Western blots of E25 or 4-3.6 whole-cell detergent extracts revealed that TrkA PY increased significantly over basal levels after short treatment with mAb 5C3 or with NGF (Fig. 5). Densitometric analysis of several blots from E25 and 4-3.6 cells is presented in Table 4. Other proteins, including $\sim 95$ and $\sim 60 \mathrm{kDa}$ proteins and the p85 subunit of PI-3 kinase $(\sim 2.5-$ fold increase; data not shown), also showed increased PY. We have estimated that $<10 \%$ of all p 85 material was tyrosinephosphorylated after ligation of TrkA.

\section{Increased cellular transformation}

NGF treatment causes the transformation and an increase in anchorage-independent growth of TrkA-expressing E25 cells (Cordon-Cardo et al., 1991). mAb 5C3 caused an approximately twofold increase in the number and size of foci compared with mIgG-treated cells (Table 5). No change in the number or size of foci was observed in wild-type NIH-3T3 cells after mAb 5C3 treatment (data not shown).

\section{Protection from cell death}

Agonistic ligands of TrkA protect receptor-expressing cells from death in SFM. Both NGF and $\mathrm{mAb} 5 \mathrm{C} 3$ increased the number of 

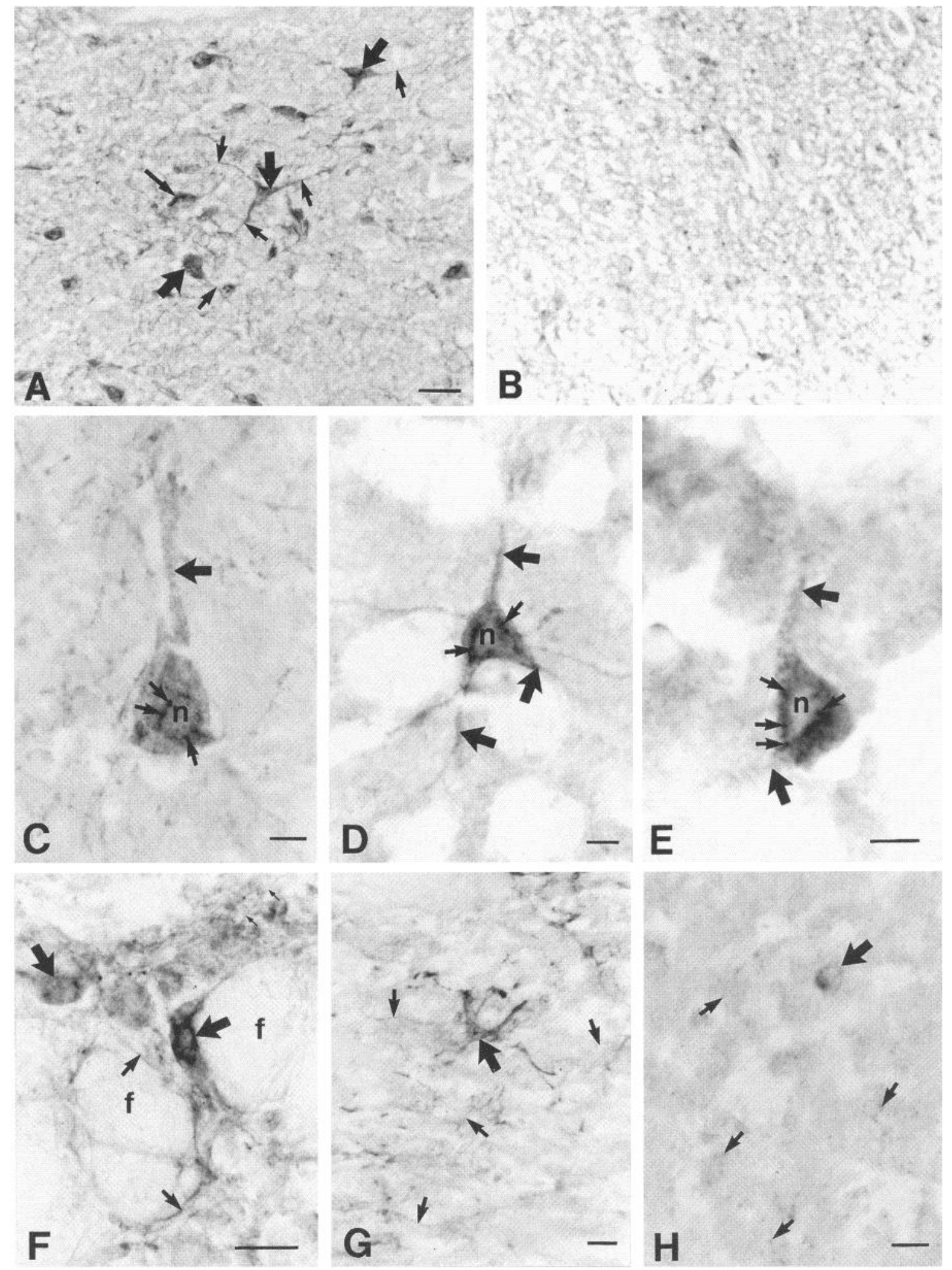

Figure 3. TrkA immunoreactivity in normal human brain. $A, B$, Low-power photomicrographs of the nucleus basalis of Meynert show large neurons (arrows) immunoreactive with mAb 5C3 $(A)$ but lacking immunoreactivity with normal mouse $\operatorname{IgG}(B)$ in a consecutive section. Note in $A$ that the labeled neuronal processes can often be followed (small arrows). $C-E$, High-power photomicrographs of TrkA-containing neurons in the nucleus basalis $(C)$, the putamen $(D)$, and the CA4 subfield of the hippocampus $(E)$. The perinuclear area displayed particularly strong concentration of diaminobenzidine precipitate (small arrows), often in granules. Labeled proximal processes also could be observed (arrows); $n$, nucleus. $F$, In the pontine nuclei, many weakly to strongly staining neurons (arrows) are observed within the fiber network (small arrows) and around the nonlabeled fiber bundles $(f)$. $G$, In the reticular formation of the brainstem, numerous fibers (small arrows) constitute a network in which some scattered neurons (arrow) are observed. $H$, Photomicrograph of TrkA immunoreactivity in the frontal cerebral cortex showing weak labeling. A few neurons are weakly positive (arrows), with the staining residing mostly in puncta, possibly corresponding to fibers (small arrows). Scale bars: $A, B, 50 \mu \mathrm{m} ; C-E, H, 10 \mu \mathrm{m} ; F, G, 20 \mu \mathrm{m}$. 


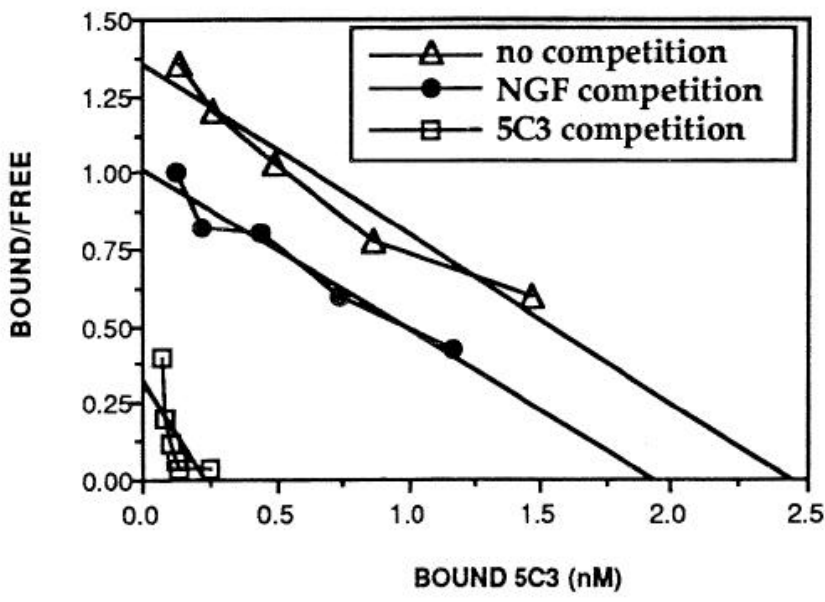

Figure 4. 5C3-binding studies and Scatchard plot analysis. Serial dilutions of $\left[{ }^{125} \mathrm{I}\right] 5 \mathrm{C} 3$ without competition (open triangles) were used in binding studies with a constant number of E25 cells. Binding was competed with molar excess of unlabeled NGF (solid circles) or mAb 5C3 (open squares). In three independent experiments, the average $K_{\mathrm{d}}$ of $\mathrm{mAb} 5 \mathrm{C} 3$ in E25 cells was $1.6 \mathrm{~nm}$. Competition with NGF reduced the average number of 5C3-binding sites, but the affinity of $\mathrm{mAb} 5 \mathrm{C} 3$ was not affected.

\section{Table 2. mAb 5C3 blocks NGF binding to TrkA}

\begin{tabular}{lc} 
Treatment & \% NGF binding \\
\hline $\mathrm{mAb} 5 \mathrm{C} 3$ & $39.3 \pm 7.4$ \\
$\mathrm{mAb} 87.92 .6$ & 100 \\
$\mathrm{NGF}(5 \mu \mathrm{M})$ & 0 \\
\hline
\end{tabular}

E25 cells expressing TrkA (but not $\mathrm{p} 75$ receptors) were incubated with [ $\left.{ }^{125} \mathrm{I}\right] \mathrm{NGF}$ in the presence of the indicated agents. [125I]NGF binding after treatment with mAb 87.92.6 was identical to treatment with vehicle binding buffer. Assays were done three times in duplicate. Data are expressed as percent binding $\pm \mathrm{SD}$, where mAb 87.92.6 is maximum and $5 \mu \mathrm{M}$ NGF is background binding as per the formula: [(test background) $\times 100 \% \mathrm{~J}($ maximum - background).

surviving/proliferating E25 fibroblastoid cells (Fig. 6). Equivalent protection also was afforded by TrkA ligands to neuronal 4-3.6 cells (data not shown). In most experiments, mAb $5 \mathrm{C} 3$ protection is dose-dependent, although high-dose antibody inhibition some-

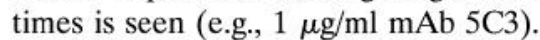

To ascertain whether cell death is apoptotic, DNA was prepared from serum-free cultured cells that showed a typical apoptotic fragmentation ladder. The DNA ladder was not seen in preparations from cells cultured in the presence of $\mathrm{mAb} 5 \mathrm{C} 3$ or NGF (data not shown).

Controls demonstrated the functional specificity of mAb $5 \mathrm{C} 3$. First, neither NGF nor mAb $5 \mathrm{C} 3$ protected wild-type NIH-3T3 cells (data not shown). Second, PC12 cells were not protected by $\mathrm{mAb} 5 \mathrm{C} 3$ but were protected by NGF (data not shown). Third, irrelevant $\mathrm{mIgG}, \mathrm{G} \alpha \mathrm{mF}_{\mathrm{ab}}$, or $\mathrm{mAb} 192$ did not protect $\mathrm{E} 25$ cells (Fig. 6) or NIH-3T3 cells (data not shown).

\section{Functional agonism of monomeric $5 \mathrm{C}_{3} \mathrm{~F}_{\mathrm{ab}} \mathrm{s}$}

Monovalent agents that bind TrkA behave as competitive antagonists (Clary et al., 1994; LeSauteur et al., 1995) likely because they cannot induce receptor dimerization. Therefore, it would be expected that monomeric $5 \mathrm{C} 3 \mathrm{~F}_{\mathrm{ab}} \mathrm{s}$ would be monovalent and not be able to mediate agonistic function.

$\mathrm{mAb} 5 \mathrm{C} 3 \mathrm{~F}_{\mathrm{ab}} \mathrm{s}$ afforded protection from apoptotic death to $\mathrm{E} 25$ cells (Fig. 6) and 4-3.6 cells (data not shown) in SFM. Moreover,

\begin{tabular}{lcl}
\hline \multicolumn{3}{l}{ Table 3. mAb 5C3-induced TrkA-receptor internalization } \\
Treatment & Temperature $\left({ }^{\circ} \mathrm{C}\right)$ & $\% 5 \mathrm{C} 3$ staining \\
\hline NGF $(2 \mathrm{nM})$ & $4^{\circ} \mathrm{C}$ & $83 \pm 2.0$ \\
& $37^{\circ} \mathrm{C}$ & $75 \pm 3.6$ \\
$5 \mathrm{C} 3(0.01 \mu \mathrm{g} / \mathrm{ml})$ & $4^{\circ} \mathrm{C}$ & $96 \pm 9.0$ \\
& $37^{\circ} \mathrm{C}$ & $77 \pm 5.5$
\end{tabular}

TrkA surface immunostaining was performed on 4-3.6 cells with mAb 5C3 after the indicated treatments and measured by FACScan analysis. Data are presented as percent staining \pm SEM, with reference to control vehicle treatment $(100 \%)$ as per the following formula: [(treated sample staining - mIgG background staining) $\times$ $100 \%] /($ maximum staining - mIgG background staining).

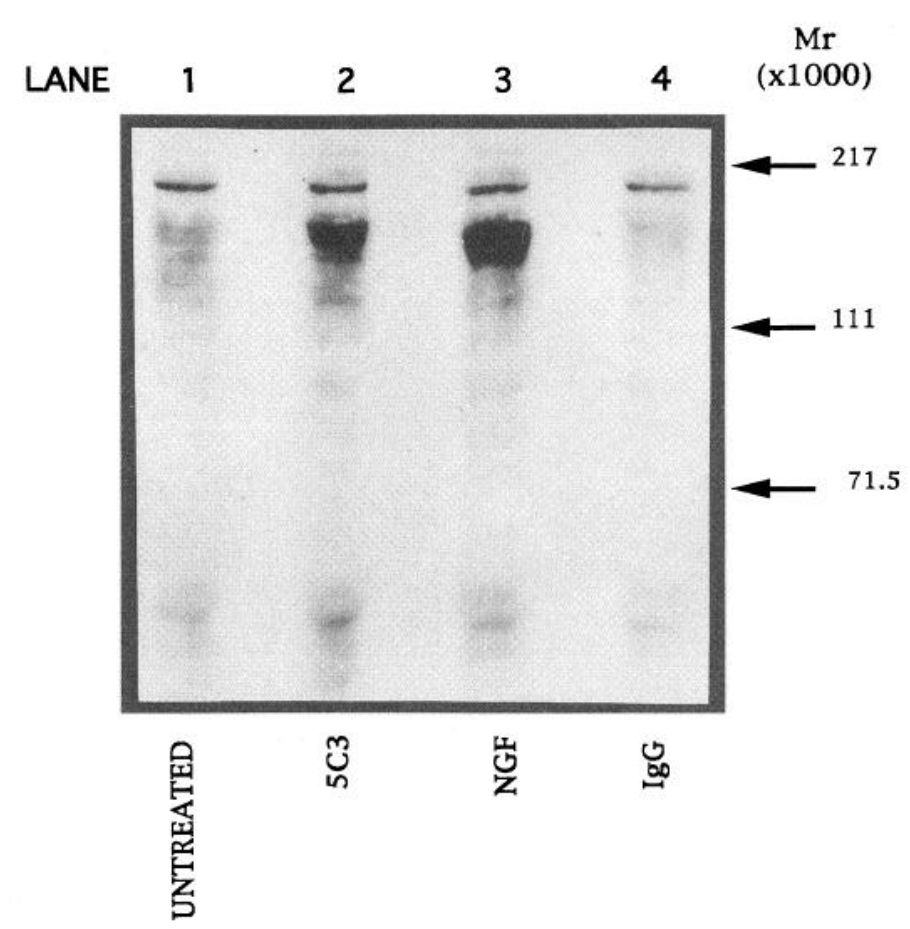

Figure 5. Induction of TrkA-PY by 5C3. E25 cells were untreated (lane 1) or treated with mAb 5C3 (lane 2), NGF (lane 3), or mIgG (lane 4) for $15 \mathrm{~min}$ at $37^{\circ} \mathrm{C}$. Whole-cell lysates were resolved in an $8 \%$ SDS-PAGE under reducing conditions and immunoblotted with anti-phosphotyrosine $\mathrm{mAb} 4 \mathrm{G} 10$. A parallel gel under nonreducing conditions immunoblotted with $\mathrm{mAb} 5 \mathrm{C} 3$ (not shown) controlled for $M_{\mathrm{r}}$ and equal loading of TrkA on all samples.

anti-phosphotyrosine Western blots revealed that cells treated with $5 \mathrm{C} 3 \mathrm{~F}_{\mathrm{ab}} \mathrm{s}$ had increased TrkA-PY similar to increases obtained with whole $\mathrm{mAb} 5 \mathrm{C} 3$ (data not shown).

Monomeric $5 \mathrm{C} 3 \mathrm{~F}_{\mathrm{ab}}$ protection was dose-dependent. However, equivalent or better protective effects were achieved when $\mathrm{F}_{\mathrm{ab}} \mathrm{s}$ were cross-linked externally with $\mathrm{G} \alpha \mathrm{mF}_{\mathrm{ab}}$ antibodies. Specificity controls included those described in the previous section for whole mAb $5 \mathrm{C} 3$, plus $192 \mathrm{~F}_{\mathrm{ab}} \mathrm{s}$ that had no protective activity in E25 cells (data not shown).

\section{DISCUSSION}

The availability of antibodies against p140 TrkA and p75 has allowed the study of these NGF receptors (Martin-Zanca et al., 1989; Eager, 1991). The mAb 5C3 reported in this study is specific for human TrkA and functions in FACScan immunofluorescence analysis, immunoprecipitation, Western blot analysis, and immu- 
Table 4. Increased TrkA-PY by mAb $5 \mathrm{C3}$

\begin{tabular}{lll} 
Treatment & E25 cells & $4-3.6$ cells \\
\hline mAb 5C3 & $2.7 \pm 0.6$ & $3.4 \pm 1.5$ \\
NGF & $6.5 \pm 1.3$ & $3.8 \pm 0.8$
\end{tabular}

E25 or 4-3.6 cells were untreated or treated with saturating concentrations of $\mathrm{mAb}$ $5 \mathrm{C} 3$ or NGF for $15 \mathrm{~min}$ at $37^{\circ} \mathrm{C}$. Whole-cell lysates or anti-PY immunoprecipitates were resolved by SDS-PAGE under reducing conditions, Western-transferred, immunoblotted with anti-phosphotyrosine mAb 4G10, and developed using ECL techniques. Optical density readings were taken from $\mathrm{x}$-ray films with film backgrounds subtracted (see Materials and Methods). Data are presented as fold increase in PY of TrkA with respect to untreated cells $\pm \mathrm{SD} ; n=3$.

Table 5. MAb 5C3-induced anchorage-independent growth

\begin{tabular}{lllr} 
Treatment & $\begin{array}{l}\text { Average number } \\
\text { of foci }^{a}\end{array}$ & $\begin{array}{l}\text { Typical } \\
\text { cells/foci }^{a}\end{array}$ & \multicolumn{1}{c}{$\begin{array}{l}\text { Fold increase } \\
\text { in foci }^{b}\end{array}$} \\
\hline $\mathrm{mIgG}$ & $416 \pm 45$ & $\sim 24$ & $1 \pm 0.11$ \\
$\mathrm{mAb} 5 \mathrm{C} 3$ & $806 \pm 178$ & $>48$ & $1.9 \pm 0.22$ \\
$\mathrm{NGF}$ & $676 \pm 51$ & $\sim 24$ & $1.6 \pm 0.08$
\end{tabular}

E25 cells were cultured in soft agar in the presence of the indicated agents for 2 weeks.

${ }^{a}$ Average number \pm SD and typical size of foci are shown.

${ }^{b}$ Fold increase in foci was calculated with respect to $\mathrm{mIgG}$-treated cells (no increase); $n=2$.

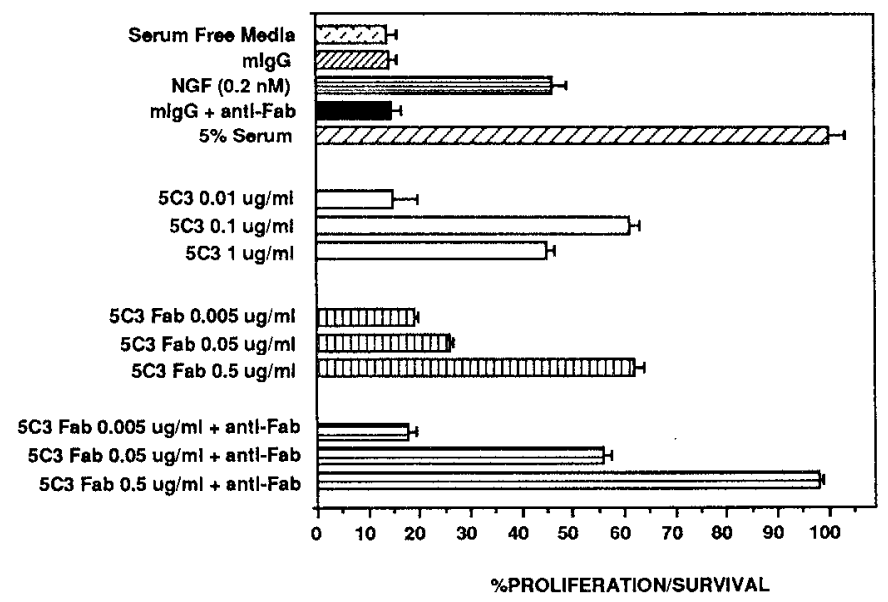

Figure 6. Protection from apoptotic death by 5C3. E25 cells were cultured in SFM supplemented with the indicated conditions for $2-3 \mathrm{~d}$, followed by the MTT assay. Similar data were obtained with neuronal 4-3.6 cells (data not shown). The percent proliferation/survival \pm SD was determined by standardizing serum-containing wells to $100 \%$ using the following formula: [(optical density of test) $\times 100 \%$ ]/(optical density of serum).

nocytochemistry. Moreover, mAb 5C3 is a structural and functional mimic of NGF.

Aberrant expression of trk $A$ mRNA and NGF responsiveness have been correlated with neurodegenerative disorders (for review, see Ebendal et al., 1991) and neoplastic malignancy (Marchetti et al., 1993; Matsushima and Bogenmann, 1993). Hence, TrkA-binding agents will be useful clinical tools in diagnosis, prognosis, and perhaps treatment of these diseases. Indeed, mAb $5 C 3$ binding is a positive prognostic marker for certain human neoplasias (K. Kramer, unpublished observations).

mAb 5C3 was used to map the distribution of TrkA protein in the normal human brain postmortem. The data are consistent with the distribution of trk $A$ mRNA and p140 TrkA protein previously described in numcrous ncurons of the basal forcbrain and striatum (Holtzman et al., 1992; Steininger et al., 1993; Allen et al., 1994; Martinoff et al., 1994). Moreover, the present study has revealed TrkA immunostaining in other cell types of the human brain including the hippocampal formation, cerebral cortex, and brainstem.

The presence of equivalent levels of TrkA protein (per weight of tissue) in the cortex and the nucleus basalis of Meynert was further supported biochemically by Western blot analysis. Quantitative differences between in situ mRNA hybridization and immunostaining may reflect increased sensitivity of the mAb $5 \mathrm{C} 3$, long TrkA protein half-life, post-transcriptional control of expression, or instability of the mRNA.

Correlation between TrkA and choline acetyltransferase immunostaining (Mesulam and Geula, 1991; De Lacalle et al., 1994) suggest that most TrkA-labeled perikarya express the cholinergic phenotype. This was confirmed by studics of colocalization (Stcininger et al., 1993; Martinoff et al., 1994). However, our results indicate that some TrkA-positive cells are not cholinergic, because the hippocampal formation does not contain intrinsic cholinergic cells in the human brain (De Lacalle et al., 1994).

$\mathrm{mAb} 5 \mathrm{C} 3$ recognizes a disulfide-stabilized domain of TrkA, and an extracellular epitope with these characteristics appears to be the NGF-docking site (Perez et al., 1995; Urfer et al., 1995). Cross-blocking studies indicated that $\mathrm{mAb} 5 \mathrm{C} 3$ and NGF can reciprocally block each other's binding to TrkA, suggesting further that the docking site of 5C3 may be similar to NGF. In addition, sequence comparison of both ligands revealed interesting homology between complementary determining regions (CDR) of $\mathrm{mAb} 5 \mathrm{C} 3$ and the variable-turn regions of $\mathrm{NGF}$ (S. Maliartchouk and $\mathrm{H}$. Saragovi, unpublished observations). Because most CDR are $\beta$-turns (Sibanda et al., 1989) and, coincidentally, the NGF structures that bind TrkA also may be $\beta$-turns (LeSauteur et al., 1995), we hypothesized that both mAb 5C3 and NGF bind to the same site on human TrkA, and cross-blocking is likely to be caused by direct competition rather than steric hindrance.

Interestingly, mAb 5C3 was more efficient at blocking NGF binding than vice versa. Only $\sim 25 \%$ of the mAb 5C3-binding sites on E25 fibroblasts were blocked by salurating doses of NGF. These data suggest that not all TrkA receptors in this transfected cell line bind NGF. It is unlikely that affinity considerations can account for these observations, because both ligands have roughly comparable $K_{\mathrm{d}}$ for TrkA (mAb 5C3, $K_{\mathrm{d}} \sim 1.6 \mathrm{nM}$; NGF, $K_{\mathrm{d}}=0.7$ nM; Jing et al., 1992) and the affinity of mAb $5 \mathrm{C} 3$ was unchanged in the presence of NGF.

Three nonexclusive possibilities can account for these observations: (1) TrkA receptors exist at equilibrium, at which $\sim 25 \%$ are in an NGF-binding conformation (e.g., dimers) and the rest are in a non-NGF-binding conformation; (2) specific post-translational modifications of TrkA receptors allow for NGF binding; and/or (3) expression of other membrane proteins [e.g., p75 or an unknown protein(s)] induces or favors the NGF-binding conformation of TrkA. These hypotheses can be addressed by biochemical analysis after differential affinity purification of TrkA with $\mathrm{mAb}$ $5 \mathrm{C} 3$ versus NGF and by further binding studies in neuronal and fibroblastoid cells expressing different receptors.

The absence of $\mathrm{mAb} 5 \mathrm{C} 3$ binding to rat TrkA is intriguing. Binding by $\mathrm{mAb} 5 \mathrm{C} 3$ to rat TrkA was expected because of the homology between $\mathrm{mAb} 5 \mathrm{C} 3 \mathrm{CDRs}$ and the variable loops of $\mathrm{NGF}$, particularly because NGF from one species does bind to TrkAs from other species. mAb $5 \mathrm{C} 3$ is a binding and structural 
mimic of NGF, with enhanced human receptor specificity. Remodeling and mutating of the CDRs of mAb $5 \mathrm{C} 3$ will yield a pan-TrkA-binding mAb. Furthermore, analysis of the epitope of $\mathrm{mAb} 5 \mathrm{C} 3$ on TrkA likely will reveal differences in the docking sites of human and rat TrkAs. This information will be useful in screening receptor-binding analogs.

To test functional mimicry by mAb $5 \mathrm{C} 3$, NGF bioassays were performed using trkA-transfected fibroblast and neuronal cells. Functional mimicry by mAb $5 \mathrm{C} 3$ included TrkA internalization, TrkA-PY, PI-3 kinase PY, increased anchorage-independent growth, and proliferation/survival of cells in SFM. By these criteria, $\mathrm{mAb} 5 \mathrm{C} 3$ is agonistic.

Increased TrkA-receptor turnover or internalization is induced by NGF binding. $\mathrm{mAb} 5 \mathrm{C} 3$ increased the internalization of TrkA, as measured by loss of cell-surface receptors. Thesc results are consistent with data that showed that E25 cells internalize $\left[{ }^{125}\right.$ I]NGF within seconds after shifting from 4 to $37^{\circ} \mathrm{C}$ (Jing et al., 1992) and that this process does not require $\mathrm{p} 75$ receptors. Thus, artificial ligands of TrkA can induce receptor internalization and could be useful in delivering toxic agents to the cytoplasma of TrkA-expressing tumors.

NGF ligation of TrkA causes receptor activation and autophosphorylation. mAb 5C3 induced TrkA-PY to a similar degree. Agonism in the absence of NGF suggests that TrkA dimerization and/or internalization is the required signaling event, rather than the formation of NGF-TrkA complexes. However, we cannot rule out that $\mathrm{mAb} 5 \mathrm{C} 3$-TrkA may be the functional signal-transducing complex.

Ligand-induced PY of the intracellular domain of 'IrkA allows for the recruitment of substrates and the activation of cytosolic proteins and nuclear oncoprotcins. $\mathrm{mAb} 5 \mathrm{C} 3$ induces the PY of proteins of $M_{\mathrm{r}} 60,85$, and $95 \mathrm{kDa}$. The $85 \mathrm{kDa}$ protein was identified as PI-3 kinase, the activation of which correlates with the actions of growth factors and oncogenes.

NGF stimulates neuronal survival and differentiation (for review, see Barbacid, 1994) and the proliferation of non-neuronal cells (Marchetti et al., 1993). NGF-activated TrkA induces transformation and morphological changes in fibroblast cells (CordonCardo et al., 1991). mAb 5C3 caused similar increases in anchorage-independent growth and foci formation in soft agar. Thus, $\mathrm{mAb} 5 \mathrm{C} 3$ can positively modulate the growth of TrkAexpressing cells. Interestingly, the size of the mAb 5C3-induced foci were larger on average than NGF-induced foci. We currently are investigating possibilities that may account for this observation.

TrkA-expressing neuronal 4-3.6 cells or fibroblastoid E25 cells undergo apoptotic death in SFM but can be rescued by NGF or $\mathrm{mAb} 5 \mathrm{C} 3$. Synergy between the two ligands occurred when combined at suboptimal doses (data not shown), as would be expected if $\mathrm{mAb} 5 \mathrm{C} 3$ bound and activated unoccupied TrkA receptors. Furthermore, morphological changes and increased attachment to plastic were observed in both NGF- and 5C3-treated cells.

Monomeric $5 \mathrm{C} 3 \mathrm{~F}_{\mathrm{ab}} \mathrm{s}$ protected E25 and 4-3.6 cells from apoptotic death. When $F_{a b}$ s were cross-linked externally using anti- $F_{a b}$ antibodies, a heightened response occurred. Because growth factor-receptor activation requires bivalent binding (Clary et al, 1994; Heldin, 1995), the monomeric $5 \mathrm{C} 3 \mathrm{~F}_{\mathrm{ab}} \mathrm{s}$ must have retained the ability to induce TrkA oligomerization. This could be explained in the following three ways: (1) $\mathrm{F}_{\mathrm{ab}}$ s are relatively large molecules capable of aggregation; (2) $5 \mathrm{C} 3 \mathrm{~F}_{\mathrm{ab}}$ binding could cause conformational changes in TrkA that induce receptor-receptor interactions; and (3) monomeric $5 \mathrm{C} 3 \mathrm{~F}_{\mathrm{ab}} \mathrm{s}$ bind to two receptor molecules in a hivalent manner. The last possibility could occur by two CDRs binding to two different TrkAs. Homology of mAb 5C3 CDRs to NGF turn regions and experiments using small recombinant antibody analogs (S. Maliartchouk and H. Saragovi, unpublished observations) support the third explanation.

$\mathrm{mAb} 5 \mathrm{C} 3$ is the first reported agonistic anti-neurotrophin receptor $\mathrm{mAb}$ and will be useful in studies of TrkA biology and for drug development. Antineoplastic effects with mAb 5C3 may be achieved through terminal differentiation, antibody-dependent cell cytotoxicity, or by the delivery of toxins or radionuclides. Furthermore, the structure of this mAb may be useful in designing peptidic and nonpeptidic TrkA-binding agents (Saragovi et al., 1991). Small, nonpeptidic agonists of TrkA should be useful pharmacological agents for the treatment of neurodegenerative diseases.

\section{REFERENCES}

Allen SJ, Dawbarn D, Eckford SD, Wilcock GK, Ashcroft M, Colebrook SM, Feeney R, MacGowan SH (1994) Cloning of a non-catalytic form of human trkB and distribution of mRN $\Lambda$ for trkB in human brain. Neuroscience 60:825-834.

Barbacid M (1994) The Trk family of neurotrophin receptors. J Neurobiol 25:1386-1403.

Bhandoola A, Cho EA, Yui K, Saragovi HU, Greene M, Quill H (1993) Reduced CD3-mediated protein tyrosine phosphorylation in anergic $\mathrm{CD}^{+}$and $\mathrm{CD}^{+}{ }^{+}$I' cells. J Immunol 151:2355-2367.

Bogenmann E, Torres M, Matsushima H (1995) Constitutive N-myc gene expression inhibits TrkA mediated neuronal differentiation. Oncogene 10:1915-1925.

Bradshaw RA, Blundell TL, Lapatto R, McDonald NQ, Murray-Rust J. (1993) Nerve growth factor revisited. Trends Biochem Sci 18:48-57

Campenot RB (1994) NGF and the local control of nerve terminal growth. J Neurobiol 25:599-611.

Cavicchioli L, Flanigan TP, Dickson JG, Vantini G, Toso RD, Fusco M, Walsh FS, Leon A (1991) Choline acetyltransferase messenger RNA expression in developing and adult rat brain: regulation by nerve growth factor. Mol Brain Res 9:319-325.

Chao MV (1992) Neurotrophin receptors: a window into neuronal differentiation. Neuron 9:583-593.

Chevalier S, Praloran V, Smith C, Mac Grogan D, Ip NY, Yancopoulos GD, Brachet P, Pouplard A, Gascan H (1994) Expression and functionality of the trkA proto-oncogene product/NGF receptor in undifferentiated hematopoietic cells. Blood 83:1479-1485.

Clary DO, Weskamp G, Austin LR, Reichardt LT (1994) TrkA crosslinking mimics neurnnal responses to nerve growth factor. Mol Biol Cell 5:549-563.

Co MS, Gaulton GM, Fields BN, Greene MI (1985) Isolation and characterization of the reovirus hemagglutinin receptors. Proc Natl $\Lambda$ cad Sci USA 82:1491-1498.

Coligan JE, Kruisbek AM, Margulies D, Shevach EM, Strober W, editors (1991) Current protocols in immunology, Sect 2.8. New York: Greene/Wiley-Interscience.

Cordon-Cardo C, Tapley P, Jing S, Nanduri V, O'Rourke E, Lamballe F, Kovary K, Klein R, Jones KR, Reichardt LF, Barbacid M (1991) The Trk tyrosine protein kinase mediates the mitogenic properties of nerve growth factor and neurotrophin-3. Cell 66:173-183.

De Lacalle S, Lim C, Sobreviela T, Mufson EJ, Hersh L, Saper CB (1994) Cholinergic innervation in the human hippocampus formation including the entorhinal cortex. J Comp Neurol 345:321-344.

Eager KB (1991) Molecular characterization of human trk protooncogene product monoclonal antibodies. Oncogene 6:819-824.

Ebendal T, Soderstrom S, Hallbook F, Ernfors P, Ibanez C, Persson H, Wetmore C, Stromberg I, Olson L (1991) Human nerve growth factor: biological and immunological activities, and clinical possibilities in neurodegenerative disease. In: Plasticity and regeneration in the nervous system (Timiras P, Privat A, eds). New York: Plenum.

Galloway CJ, Madanat MS, Sarr T, Espevik T, Dumas ML, Mitra G, Ranges GE (1992) Anti-tumor necrosis factor receptor and tumor necrosis factor agonist activity by an anti-idiotypic antibody. Eur $\mathbf{J}$ Immunol 22:3045-3048.

Gefter MAS (1977) Procedure for the fusion of spleen cells with P3X63/ Ag8 cells. Somatic Cell Genet 3:231-251. 
Hansen MB, Nielsen SE, Berg K (1989) Reexamination and further development of a precise and rapid dye method for measuring cell growth/cell kill. J Immunol Methods 119:203-210.

Harlow E, Lane D (1988) Antibodies: a laboratory manual, pp 332-333. Cold Spring Harbor, NY: Cold Spring Harbor Laboratory.

Heldin C-H (1995) Dimerization of cell surface receptors in signal transduction. Cell 80:213-223.

Hempstead BL, Martin-Zanca D, Kaplan DR, Parada LF, Chao MV (1991) High-affinity NGF binding requires coexpression of the trk proto-oncogene and the low-affinity $\mathrm{NGF}$ receptor. Nature 350:678-683.

Heumann R, Schwab M, Merkl R, Thoenen H (1984) Nerve growth factor-mediated induction of choline acetyl transferase in PC12 cells: evaluation of the site of action of nerve growth factor and the involvement of lysosomal degradation products of nerve growth factor. $\mathbf{J}$ Neurosici 4:3039-3050.

Holtzman DM, Li Y, Parada LF, Kinsman S, Chen C-K, Valleta JS, Zhou J, Long JB, Mobley WC (1992) P140 trk mRNA marks NGFresponsive forebrain neurons: evidence that trk gene expression is induced by NGF. Neuron 9:465-478.

Hsu S-M, Rainer L, Farnger H (1981) Use of avidin-biotin-peroxidase complex $(\mathrm{ABC})$ in immunoperoxidase techniques: a comparison between $\mathrm{ABC}$ and unlabeled antibody (PAP) procedures. J Histochem Cytochem 29:577-580.

Jing S, Tapley P, Barbacid M (1992) Nerve growth factor mediates signal transduction through Trk homodimer receptors. Neuron 9:1067-1079.

Kaplan DR, Stephens RM (1994) Neurotrophin signal transduction by the Trk receptor. J Neurobiol 25:1404-1417.

Kaplan DR, Hempstead BI, Martin-7anca D, Chao MV, Parada LF (1991) The trk proto-oncogene product: a signal transducing receptor for nerve growth factor. Science 252:554-558.

Klein R, Jing S, Nanduri V, O'Rourke E, Barbacid M (1991) The trk proto-oncogene encodes a receptor for nerve growth factor. Cell 65:189-197.

LeSauteur L, Wei L, Gibbs B, Saragovi HU (1995) Small peptide mimics of nerve growth factor bind TrkA receptors and affect biological responses. J Biol Chem 270:6564-6569.

Mahadeo D, Kaplan L, Chao MV, Hempstead BL (1994) High affinity nerve growth factor binding displays a faster rate of association than p140 Trk binding. J Biol Chem 269:6884-6891.

Marchetti D, Menter D, Jin L, Nakajima M, Nicolson GL (1993) Nerve growth factor effects on human and mouse melanoma cell invasion and heparinase production. Int J Cancer 55:692-699
Martinoff R, Chen E-Y, Poller EH, Sladek Jr JR, Mufson EJ, Kordower JH (1994) Trk-immunoreactivity in the forebrain of young and aged non-human primates. Soc Neurosci Abstr 20:11-25.

Martin-Zanca D, Oskam R, Mitra G, Copcland T, Barbacid M (1989) Molecular and biochemical characterization of the human trk protooncogene. Mol Cell Biol 9:24-33.

Matsushima H, Bogenmann E (1993) Expression of TrkA cDNA in neuroblastomas mediates differentiation in vitro and in vivo. Mol Cell Biol 13:7447-7450.

Mesulam MM, Geula C (1991) Acetylcholinesterase-rich neurons of the human cerebral cortex: cytoarchitectonic and ontogenic patterns of distribution. J Comp Neurol 306:193-220.

Perez P, Coll PM, Hempstead BL, Martin-Zanca D, Chao MV (1995) NGF binding to the Trk tyrosine kinase receptor requires the extracellular immunoglobulin-like domains. Mol Cell Neurosci 6:97-105.

Saragovi HU, Fitzpatrick D, Raktabutr A, Nakanishi H, Kahn M, Greene MI (1991) Design and synthesis of a mimetic from an antibody complementarity-determining region. Science 253:792-795.

Sibanda BL, Blundell TL, Thorton JM (1989) Conformation of $\beta$-hairpins in protein structure. J Mol Biol 206:759-777.

Soltoff SP, Rabin SL, Cantley LC, Kaplan DR (1992) Nerve Growth Factor promotes the activation of phosphatidylinositol-3 kinase and its association with the 'Irk tyrosine-kinase. J Biol Chem 267:17472-17477.

Steininger TL, Wainer BH, Klein R, Barbacid M, Palfrey HC (1993) High affinity nerve growth factor receptor (Trk) immunoreactivity is localized in cholinergic neurons of the basal forebrain and striatum in the adult rat brain. Brain Res 612:330-335.

Taub R, Greene MI (1992) Functional validation of ligand mimicry by anti-receptor antibodies: structural and therapeutic implications. Biochemistry 31:7431-7435.

'Iwyman RE, Gahring LC', Spiess J, Kogers SW (1995) Glutamate receptor antibodies activate a subset of receptors and reveal an agonist binding site. Neuron 14:755-762.

Urfer R, Tsoulfas P, O'Connell L, Shelton DL, Parada LF, Presta LG (1995) An immunoglobulin-like domain determines the specificity of neurotrophin receptors. EMBO J 14:2795-2805.

Verge VMK, Merlio J-P, Grondin J, Ernfors P, Persson H, Riopelle RJ, Hokfelt T, Richardson PM (1992) Colocalization of NGF binding sites, trk mRNA, and low-affinity NGF receptor mRNA in primary sensory neurons: response to injury and infusion of NGF. $J$ Neurosci 12:4011-4022. 